\title{
Presynaptic P2X Receptors Facilitate Inhibitory GABAergic Transmission between Cultured Rat Spinal Cord Dorsal Horn Neurons
}

\author{
Sylvain Hugel and Rémy Schlichter \\ Laboratoire de Neurophysiologie Cellulaire et Intégrée, Unité Mixte de Recherche 7519-Centre National de la Recherche \\ Scientifique, Université Louis Pasteur, 67084 Strasbourg Cedex, France
}

\begin{abstract}
The superficial layers of the spinal cord dorsal horn (DH) express $\mathrm{P} 2 \mathrm{X} 2$, $\mathrm{P} 2 \mathrm{X} 4$, and $\mathrm{P} 2 \mathrm{X} 6$ subunits entering into the formation of ionotropic (P2X) receptors for ATP. Using a culture system of laminae I-III from neonatal rat $\mathrm{DH}$, we show that ATP induced a fast nonselective cation current in $38 \%$ of the neurons (postsynaptic effect). ATP also increased the frequency of miniature IPSCs (mIPSCs) mediated by $\mathrm{GABA}_{\mathrm{A}}$ receptors or by glycine receptors in 22 and $9 \%$, respectively, of the neurons tested (presynaptic effect) but had no effect on glutamatergic transmission. The presynaptic effect of ATP on GABAergic transmission was not significantly affected by thapsigargin (1 $\mu \mathrm{M})$ but was completely dependent on $\mathrm{Ca}^{2+}$ influx. Presynaptic and postsynaptic effects were inhibited by suramin, pyridoxalphosphate-6-azophenyl-2' ${ }^{\prime} 4^{\prime}$-disulfonic acid, and reactive blue and were not reproduced by uridine $5^{\prime}$-triphosphate (UTP) or adenosine 5'-O-(2-thiodiphosphate) (ADP- $\beta$-S), sug-
\end{abstract}

gesting the implication of ionotropic $\mathrm{P} 2 \mathrm{X}$ rather than of metabotropic P2Y receptors. $\alpha \beta$-methylene-ATP $(100 \mu \mathrm{M})$ did not reproduce the effects of ATP. ATP reversibly increased the amplitude of electrically evoked GABAergic IPSCs and reduced paired-pulse inhibition or facilitation without affecting IPSC kinetics. This effect was preferentially, but not exclusively, observed in neurons coreleasing ATP and GABA. We conclude that in cultured DH neurons, the effects of ATP are mediated by P2X receptors having a pharmacological profile dominated by the P2X2 subunit. The presynaptic receptors might underlie a modulatory action of ATP on a subset of GABAergic interneurons involved in the spinal processing of nociceptive information.

Key words: dorsal horn; spinal cord; nociception; purine; $G A B A_{A}$ receptor; inhibitory postsynaptic current; IPSC; synaptic transmission; presynaptic modulation
ATP plays an important role in cell metabolism but acts also as a neurotransmitter (Surprenant et al., 1995; Burnstock, 1997; MacDermott et al., 1999). The fast ATP-mediated excitatory synaptic component involves the activation of ionotropic $\mathrm{P} 2 \mathrm{X}$ receptors, but ATP can also activate G-protein-coupled metabotropic (P2Y) receptors to alter the excitability of postsynaptic neurons (Burnstock, 1997; North and Barnard, 1997; Ralevic and Burnstock, 1998). Moreover, ATP can be coreleased with a classical neurotransmitter at peripheral as well as central synapses (Burnstock, 1997; Jo and Schlichter, 1999).

To date seven distinct $\mathrm{P} 2 \mathrm{X}$ subunits (P2X1-P2X7) have been cloned, six of which (P2X1-P2X6) are expressed in the CNS (Collo et al., 1996; Vulchanova et al., 1997; Le et al., 1998b; Kanjhan et al., 1999). In situ hybridization studies have indicated that P2X4 and P2X6 subunits, and to a lesser extent P2X2, are widely distributed throughout the CNS (Collo et al., 1996) and could therefore underlie the fast excitatory membrane effects of

Received Sept. 24, 1999; revised Dec. 23, 1999; accepted Jan. 4, 2000.

This work was supported by a grant from the Institut UPSA de la Douleur. We acknowledge additional support from Université Louis Pasteur (Strasbourg), Centre National de la Recherche Scientifique (CNRS, France), and Institut Universitaire de France. Many thanks to Dr. Yves de Koninck (Mc Gill University, Montreal, Canada) for providing his synaptic current analysis program and to Dr. Jean-Luc Rodeau (UPR9009, CNRS, Strasbourg) for his Kolmogorov-Smirnov analysis software. We thank Catherine Moreau and Madeleine Roth for excellent technical assistance.

Correspondence should addressed to $\mathrm{R}$ Schlichter, Unité Mixte de Recherche 7519-Centre National de la Recherche Scientifique, Université Louis Pasteur, 21 rue Descartes, 67084 Strasbourg Cedex, France. E-mail: schlichter@neurochem.ustrasbg.fr.

Copyright (C) 2000 Society for Neuroscience $0270-6474 / 00 / 202121-10 \$ 15.00 / 0$
ATP. However, the existence of fast P2X receptor-mediated synaptic transmission has been demonstrated only in a relatively limited number of CNS structures: the medial habenula (Edwards et al., 1992), the locus coeruleus (Nieber et al., 1997), the spinal cord (Bardoni et al., 1997; Jo and Schlichter, 1999), and the hippocampus (Pankratov et al., 1998). Moreover, immunocytochemical studies have shown that P2X subunits are present on the soma and the dendrites of postsynaptic neurons as well as on presynaptic terminals (Vulchanova et al., 1997; Le et al., 1998b; Kanjhan et al., 1999), raising the possibility that ATP could modulate synaptic transmission at CNS synapses by both postsynaptic and presynaptic actions.

The dorsal horn (DH) of the spinal cord gray matter is involved in the processing of nociceptive (painful) messages (Millan, 1999), and ATP was shown to play an important role in the modulation of nociceptive messages at the spinal level (Salter et al., 1993). In fact, purines exert complex effects in the DH because ATP excites DH neurons (Jahr and Jessell, 1983; Li and Perl, 1995), whereas adenosine, which results from the extracellular degradation of ATP by ectonucleotidases (Zimmermann, 1994, 1996), has inhibitory effects (Salter et al., 1993). Postsynaptic ionotropic receptors are known to underlie fast synaptic transmission in the nervous system, and at the presynaptic level such ionotropic receptors are also likely to modulate the release of neurotransmitters (MacDermott et al., 1999). P2X receptors are involved in ATP-mediated facilitation of glutamate release from primary sensory afferents in the spinal cord (Li and Perl, 1995; Gu and MacDermott, 1997) and in the brain stem (Khakh and Henderson, 1998). Yet, there has been no report concerning a 
presynaptic $\mathrm{P} 2 \mathrm{X}$ receptor-mediated modulatory effect on synaptic transmission between CNS neurons. We have recently shown the existence of a close relationship between ATP and GABA in cultured laminae I-III DH neurons (Jo and Schlichter, 1999), and the present study, was aimed at searching for possible presynaptic effects of ATP in particular on GABAergic synaptic transmission.

\section{MATERIALS AND METHODS}

Tissue culture. The technique for preparing primary cultures of spinal dorsal horn neurons was described in detail elsewhere (Jo et al., 1998a,b). Briefly, after decapitation of 3- to 4-d-old Wistar rats under deep diethylether anesthesia, a laminectomy was performed, and the dorsal third of the spinal cord was cut with a razor blade. The tissue fragments were digested enzymatically for $45 \mathrm{~min}$ at $37^{\circ} \mathrm{C}$ with papain $(20 \mathrm{U} / \mathrm{ml}$, Sigma, St. Louis, MO) in oxygenated divalent-free Earle's balanced salt solution (EBSS, Life Technologies, Gaithersburg, MD). The enzymatic digestion was stopped by adding $3 \mathrm{ml}$ EBSS containing bovine serum albumin (1 $\mathrm{mg} / \mathrm{ml}$; Sigma), trypsin inhibitor $(10 \mathrm{mg} / \mathrm{ml}$; Sigma), and DNase $(0.01 \%$; Sigma), and a mechanical dissociation was performed with a $1 \mathrm{ml}$ plastic pipette. The homogenate was deposited on top of $4 \mathrm{ml}$ of a solution of composition similar to that described above, except that the concentration of bovine serum albumin was increased to $10 \mathrm{mg} / \mathrm{ml}$. After centrifugation ( $5 \mathrm{~min}$ at $500 \mathrm{rpm}$ ), the supernatant was removed and replaced with $5 \mathrm{ml}$ of culture medium the composition of which was the following: MEM- $\alpha$ (Life Technologies), fetal calf serum (5\% vol/vol; Life Technologies), heat-inactivated horse serum (5\% vol/vol; Life Technologies), penicillin and streptomycin (50 IU $/ \mathrm{ml}$ for each; Life Technologies), transferrin (10 mg/ml; Sigma), insulin (5 mg/ml; Sigma), putrescine (100 $\mathrm{nM}$; Sigma), and progesterone (20 nM; Sigma). After trituration with a fire-polished Pasteur pipette, the cells were plated on $35 \mathrm{~mm}$ collagencoated plastic culture dishes in the central compartment, which was delimited by a small (internal diameter $15 \mathrm{~mm}$ ) circular glass ring. This ring was glued onto the bottom of the dish with paraffin wax and could easily be removed before electrophysiological experiments. Cultures were maintained in a water-saturated atmosphere $\left(95 \%\right.$ air, $\left.5 \% \mathrm{CO}_{2}\right)$ at $37^{\circ} \mathrm{C}$ until use $(10-15 \mathrm{~d})$. Two days after the cells were seeded, cytosine arabinoside $(10 \mu \mathrm{M})$ was added to the culture medium for $24 \mathrm{hr}$ to reduce glial proliferation.

Electrophysiological recordings. Experiments were performed at room temperature $\left(20-22^{\circ} \mathrm{C}\right)$ after $10-15 \mathrm{~d}$ in culture. Patch-clamp recordings were made with the perforated patch-clamp technique using amphotericin B as the pore-forming agent (Rae et al., 1991) with an Axopatch 200A amplifier (Axon Instruments, Foster City, CA) and low-resistance (3-4 $\mathrm{M} \Omega$ ) electrodes. The external solution contained (in $\mathrm{mM}$ ): $\mathrm{NaCl}$ $135, \mathrm{KCl} 5, \mathrm{CaCl}_{2} 2.5, \mathrm{MgCl}_{2}$ 1, HEPES 5, and glucose 10, $\mathrm{pH} 7.35$. The external solution also contained 6-cyano-7-nitroquinoxaline-2,3-dione (CNQX, $10 \mu \mathrm{M}$ ), D-amino-phosphonovaleric acid (D-APV, $30 \mu \mathrm{M}$ ), and strychnine $(1 \mu \mathrm{M})$ to block fast glutamatergic and glycinergic synaptic transmissions and tetrodotoxin (TTX, $0.5 \mu \mathrm{M}$ ), which blocks $\mathrm{Na}^{+}$dependent action potential propagation, to record GABAergic miniature IPSCs (mIPSCs) in isolation. When testing the effect of ATP on glutamatergic or glycinergic transmissions, CNQX and APV or strychnine were omitted from the external medium and bicuculline $(10-20 \mu \mathrm{M})$ was added. In some experiments, in which we wanted to prevent an ATPmediated depolarization of the presynaptic terminals, all external $\mathrm{NaCl}$ was replaced by an equimolar amount of $\mathrm{N}$-methyl-D-glucamine chloride (NMDG-Cl). When the extracellular $\mathrm{CaCl}_{2}$ concentration was reduced to $0.3 \mathrm{~mm}$, the $\mathrm{MgCl}_{2}$ concentration was increased to $5 \mathrm{~mm}$. The pipette was first filled at its tip with a solution containing (in $\mathrm{mM}$ ): $\mathrm{CsCl} 125$,

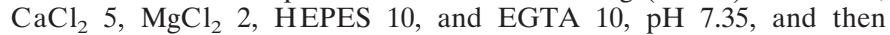
backfilled with the same solution containing amphotericin B $(150 \mu \mathrm{g} / \mathrm{ml})$. The amphotericin B (Sigma) stock solution $(30 \mathrm{mg} / \mathrm{ml})$ was prepared in dimethyl sulfoxide (DMSO) just before the recording session. Voltage and current traces were stored digitally on a videotape recorder (sampling rate $20 \mathrm{kHz}$ ) and/or on a personal computer after being filtered at $5 \mathrm{kHz}$ by the Axopatch 200A. Acquisition and analysis were performed with Axograph 3 (Axon Instruments) and more recently with the program SYNAPSE (developed and kindly supplied by Dr. Y. De Koninck, McGill University, Montreal, Canada). General principles and details on the analysis of synaptic currents can be found elsewhere (Poisbeau et al., 1996; Jo et al., 1998a). The analysis of miniature synaptic currents was performed on sequences with at least 300 events each. This corresponded typically to 2 min of recording in control conditions and the complete sequence $(\sim 30 \mathrm{sec})$ during the application of P2X receptor agonists. All
mIPSCs analyzed were selected manually on the basis of their rapid rise times (RTs) and exponential decay kinetics.

Electrical stimulation. To study the effect of ATP on action potentialevoked release of GABA, we stimulated electrically (extracellular stimulation) the cell body of a visually identified neuron establishing an apparent physical contact with the neuron from which we recorded. The stimulation procedure was identical to that described previously for the same culture preparation (Jo et al., 1998a; Jo and Schlichter, 1999). Stimulation was performed with short pairs (interval $400 \mathrm{msec}$ ) of stimuli ( $0.1 \mathrm{msec}$ in duration) delivered at $0.1 \mathrm{~Hz}$. Their amplitude was between -10 and $-20 \mathrm{~V}$. In these experiments, $E_{\mathrm{Cl}}$ was fixed at $-90 \mathrm{mV}$ by replacing $146 \mathrm{~mm} \mathrm{CsCl}$ with $75 \mathrm{mM} \mathrm{Cs}_{2} \mathrm{SO}_{4}$ in the pipette solution, whereas the equilibrium potential for cations $\left(E_{\text {Cations }}\right)$ remained at 0 $\mathrm{mV}$. TTX was omitted from the extracellular medium to allow action potential generation and propagation in the presynaptic neuron. Under such conditions it was possible to determine whether the neuron stimulated electrically was coreleasing ATP and GABA or if it was releasing GABA alone (Jo and Schlichter, 1999) because P2X receptor-mediated inward EPSCs could be recorded in isolation at a holding potential (HP) of $-90 \mathrm{mV}$, whereas GABAergic IPSCs were recorded in isolation at an $\mathrm{HP}$ of $0 \mathrm{mV}$. We routinely first verified the presence or absence of electrically evoked P2X receptor-mediated inward EPSCs at an HP of $-90 \mathrm{mV}$ before setting the HP at $0 \mathrm{mV}$ and testing the effect of ATP on GABAergic electrically evoked IPSCs (eIPSCs). For analysis, we averaged on one hand 10-20 traces recorded under control or wash-out conditions and on the other hand the 10 traces recorded during the application of ATP $(100 \mu \mathrm{M})$, which lasted $100 \mathrm{sec}$. The paired-pulse inhibition or facilitation ratio $(R)$ was determined as $R=\left(I_{2}-I_{1}\right) \cdot 100$ / $I_{1}$, where $R$ is expressed as percentage, $I_{1}$ is the amplitude of the first eIPSC, and $I_{2}$ is the amplitude of the second eIPSC. $R$ had a negative value in the case of paired-pulse inhibition and a positive value in case of paired-pulse facilitation. We first determined $R$ under control conditions and then during the application of ATP $(100 \mu \mathrm{M})$. The change in paired-pulse ratio was calculated as follows for each neuron tested: change in paired-pulse ratio (in $\%)=\left(R_{1}-R_{2}\right) \cdot 100 / R_{1}$, with $R_{1}$ and $R_{2}$ representing the paired-pulse ratios under control conditions and in the presence of ATP $(100 \mu \mathrm{M})$, respectively.

Drugs and application of substances. All substances were prepared as 1000 times concentrated stock solutions. Bicuculline (Sigma), strychnine (Sigma), TTX (Latoxan), ATP (Sigma), adenosine 5'-O-(3-thiotriphosphate) (ATP- $\gamma$-S; Sigma), UTP (Sigma), $\alpha, \beta$-methylene ATP $(\alpha, \beta$-meATP; Sigma), ADP (Sigma), adenosine 5'-O-(2-thiodiphosphate) (ADP$\beta$-S; Sigma), suramin (Sigma), pyridoxalphosphate-6-azophenyl-2' $4^{\prime}$ disulfonic acid (PPADS; Tocris Cookson, distributed by Bioblock), reactive blue (Sigma), and isoguvacine (Peninsula Laboratories, Belmont, CA) were prepared in distilled water, and D-APV (30 mM; Sigma) was prepared in $\mathrm{NaOH}(1 \mathrm{M})$. All these stock solutions were stored at $-20^{\circ} \mathrm{C}$. CNQX (Tocris Cookson, distributed by Bioblock) and thapsigargin (Sigma) were prepared in DMSO and stored at $4^{\circ} \mathrm{C}$.

The substances to be tested were dissolved at their final concentrations in extracellular solution just before the recording session. ATP antagonists, with the exception of reactive blue, were applied by bath perfusion, and ATP agonists were applied by local perfusion using a U-tube. In the case of the antagonists suramin and PPADS, the same concentration of antagonist was also included in the U-tube solution along with the agonist to be applied locally. The antagonist reactive blue was coapplied with ATP agonists by means of the U-tube in the absence of reactive blue in the bath solution. In electrical stimulation experiments, all substances were applied by bath perfusion at rate of $2-3 \mathrm{ml} / \mathrm{min}$, which allowed relatively rapid application of substances because the recordings were performed in a central chamber (of the culture dish) having a total volume of $250 \mu \mathrm{l}$.

All statistical results are given as mean \pm SEM.

Statistical differences between results were determined using Student's $t$ test or one-way ANOVA (Origin, Microcal software) by setting the confidence interval at 0.05 . Differences in cumulative probability distributions were determined by a Kolmogorov-Smirnov test (program written and kindly supplied by Dr. Jean-Luc Rodeau, Strasbourg).

\section{RESULTS}

In an initial phase of this work, we tested the effect of ATP $(30-100 \mu \mathrm{M})$ in the absence of any antagonist of ionotropic glutamate, glycine, or GABA receptors. Under these conditions we noticed that ATP induced a fast membrane current charac- 
teristic of the activation of ionotropic receptors or increased the frequency of spontaneously occurring synaptic events or both. The latter had relatively slow deactivation time constants (35-40 msec) that are characteristic of $\mathrm{GABA}_{\mathrm{A}}$ receptor-mediated IPSCs in our preparation (Jo and Schlichter, 1999) (see below). However, to assess the specificity of the facilitatory action of ATP on GABAergic transmission, we tested its effect on pharmacologically isolated glutamatergic and glycinergic transmissions. All experiments were performed in the presence of TTX $(0.5 \mu \mathrm{M})$ to record miniature synaptic currents in isolation and to avoid the activation of polysynaptic pathways.

\section{Glutamatergic transmission}

Glutamatergic miniature EPSCs (mEPSCs) were recorded in the presence of strychnine $(1 \mu \mathrm{M})$ and bicuculline $(10 \mu \mathrm{M})$. We recorded from 20 neurons displaying glutamatergic mEPSCs. In all cases, ATP $(100 \mu \mathrm{M})$ failed to increase the frequency of mEPSCs, indicating that ATP did not modulate presynaptically glutamate release between cultured DH neurons.

\section{Glycinergic transmission}

Glycinergic mIPSCs were recorded in 23 neurons in the presence of CNQX $(10 \mu \mathrm{M})$, D-APV $(30 \mu \mathrm{M})$, and bicuculline $(10 \mu \mathrm{M})$. ATP $(100 \mu \mathrm{M})$ increased the frequency of glycinergic mIPSCs in 2 of 23 cases, i.e., $9 \%$ of the cells tested. This result suggested that ATP was likely to facilitate presynaptically glycine release from a small subset of glycinergic synapses. The rarity of these ATPsensitive glycinergic synapses, at least in our culture system, precluded a detailed pharmacological study on the subtypes of ATP receptors involved in this modulatory phenomenon.

It appeared, however, that the effect of ATP was more frequently observed on GABAergic transmission (see below), and we decided to study this point in more detail.

\section{Dual effect of ATP on cultured dorsal horn neurons}

All experiments described below were performed in the presence of blockers of glutamatergic and glycinergic transmissions (CNQX $10 \mu \mathrm{M}, \mathrm{D}-\mathrm{APV} 30 \mu \mathrm{M}$, strychnine $1 \mu \mathrm{M}$ ) and in the presence of $0.5 \mu \mathrm{M}$ TTX (except in electrical stimulation experiments). The HP was $-60 \mathrm{mV}$ if not stated otherwise.

\section{Postsynaptic effect of $A T P$}

ATP (30-100 $\mu \mathrm{M})$ induced a fast inward current (rise-time $\leq 1$ sec) in 60 of 156 neurons (38\%). This response was accompanied by an increase in membrane noise that recovered quickly after cessation of ATP application (Fig. 1A). Moreover, the ATP response displayed little desensitization as indicated by similar amplitudes of membrane currents when ATP applications were repeated at short $(<5-10 \mathrm{sec})$ intervals or by the limited attenuation (typically $<30 \%$ ) of the current during prolonged ( $\geq 10 \mathrm{sec}$ ) ATP applications (Fig. 1A). The mean amplitude of the peak currents induced by ATP $(100 \mu \mathrm{M})$ at a holding potential of -60 $\mathrm{mV}$ was $39 \pm 41 \mathrm{pA}(n=41$, range $5-175 \mathrm{pA})$.

As illustrated in Figure $1 B$, the reversal potential of the ATPgated current was close to $0 \mathrm{mV}$, a value that was compatible with the activation of a nonselective cation conductance (Jo and Schlichter, 1999). The $I-V$ relationship showed marked inward rectification at negative membrane potentials, a phenomenon that is classically observed with ionotropic ATP-gated receptors (P2X receptors) as well as with other calcium permeable ligand-gated channels (Jonas and Burnashev, 1995; Burnashev, 1996).
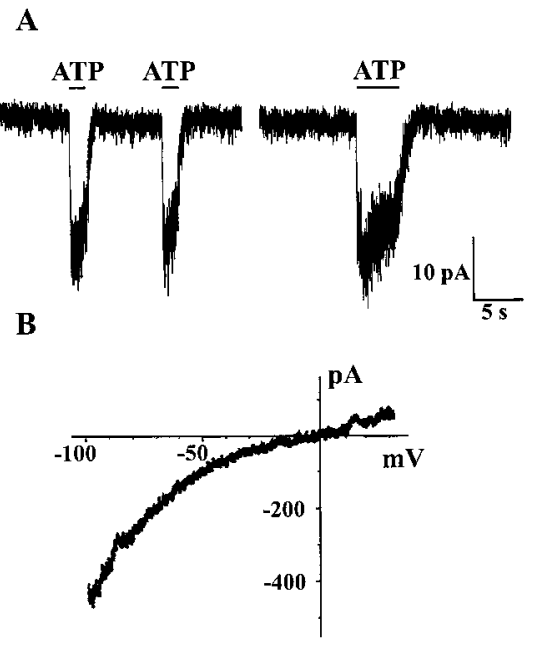

C1

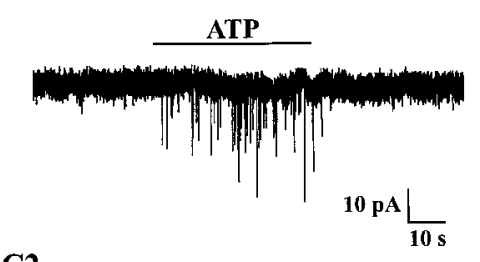

C2

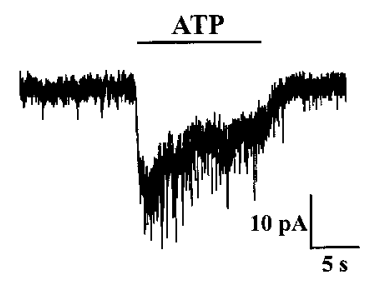

Figure 1. Presynaptic and postsynaptic effects of ATP in cultured DH neurons. In this and all other figures, recordings were made in the presence of CNQX $(10 \mu \mathrm{M})$, D-APV $(30 \mu \mathrm{M})$, and strychnine $(1 \mu \mathrm{M})$ in the extracellular medium to block fast glutamatergic and glycinergic synaptic transmissions. TTX $(0.5 \mu \mathrm{M})$ was also present to record GABAergic mIPSCs. $A$, Local applications of ATP induced fast inward currents in the postsynaptic neuron. Two successive and close (10 sec interval) ATP $(100 \mu \mathrm{M})$ applications elicited currents of similar amplitudes. During a long-lasting $(5 \mathrm{sec})$ application of ATP, the current decayed only partially and slowly, indicating the absence of significant desensitization. $B$, Current-voltage $(I-V)$ relationship of the ATP (100 $\mu \mathrm{M})$-induced current obtained by applying a 2 sec lasting monotonic voltage ramp from $-100 \mathrm{mV}$ to $+30 \mathrm{mV}$. The reversal potential was close to $0 \mathrm{mV}$, and the $I-V$ relationship showed marked inward rectification at negative membrane potentials. $C 1$, Application of ATP $(100 \mu \mathrm{M})$ reversibly increased the frequency of mIPSCs recorded as fast downward deflections of the current trace. C2, Coexistence of presynaptic and postsynaptic effects of ATP. In some cells, ATP $(100 \mu \mathrm{M})$ induced both an inward current and an increase in mIPSC frequency. All traces were recorded at an $\mathrm{HP}$ of $-60 \mathrm{mV}$. In $A, C 1$, and $C 2$, the horizontal black bars represent the duration of ATP application.

\section{Presynaptic effect of $A T P$}

Local application of ATP (30-100 $\mu \mathrm{M})$ increased the frequency of GABAergic mIPSCs in 33 of 149 neurons (22\%) recorded, indicating the existence of a facilitatory effect of ATP on synaptic GABA release. Two types of effects of ATP were observed (Fig. $1 C$ ). In $58 \%$ of the cases (19 of 33 neurons) ATP simply increased the frequency of mIPSCs in a reversible manner, whereas in the remaining $42 \%$ of the neurons (14 of 33), the presynaptic facilitation of GABA release was associated with a tonic fast postsyn- 
$\mathbf{A}$
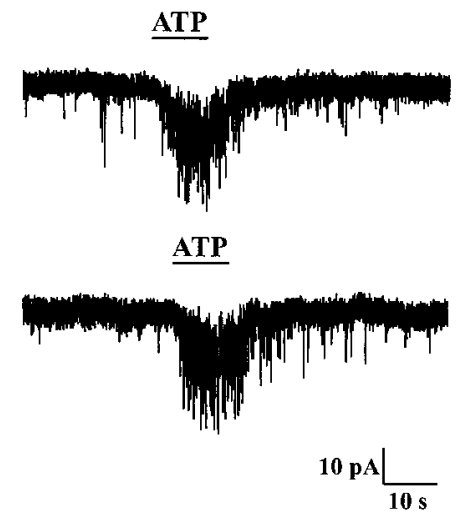

B
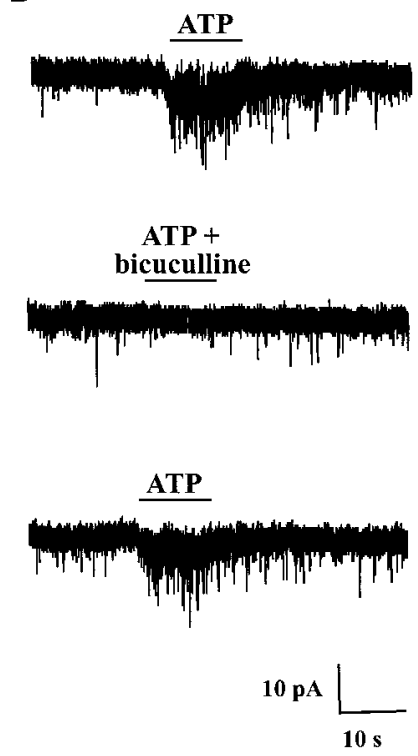

Figure 2. ATP increased the frequency of GABAergic mIPSCs in a reproducible manner. $A$, Two successive ATP $(100 \mu \mathrm{M})$ applications spaced by a 2 min interval induced a similar (reproducible) increase in mIPSC frequency. $B$, When coapplied with bicuculline $(10 \mu \mathrm{M})$, a selective antagonist of $\mathrm{GABA}_{\mathrm{A}}$ receptors, ATP $(100 \mu \mathrm{M})$ no longer increased the frequency of synaptic events, indicating that ATP increased the frequency of $\mathrm{GABA}_{\mathrm{A}}$ receptor-mediated mIPSCs. The inward current developing slowly during the application of ATP was caused by the temporal summation of mIPSCs but not by a direct activation of postsynaptic ATP receptors, as demonstrated by its blockade by bicuculline. HP, $-60 \mathrm{mV}$.

aptic inward current that had the same characteristics as that of the postsynaptic ATP-induced current described in the preceding section (i.e., a rise-time $\leq 1 \mathrm{sec}$ ). The mean increase in frequency of synaptic currents was of $101 \pm 36 \%(n=8), 287 \pm 185 \%(n=$ 7 ), and $280 \pm 205 \%(n=18)$ for 30,50 , and $100 \mu \mathrm{M} \mathrm{ATP,}$ respectively, an increase of $100 \%$, meaning a doubling of the initial frequency. The values for the three concentrations tested were not significantly different (one-way ANOVA, $p>0.05$ ). When all results were pooled the mean increase in frequency of mIPSCs was $254 \pm 197 \%(n=33$, range $32-686 \%)$.

As in the case of the postsynaptic current induced by ATP, the increase in frequency of mIPSCs induced by ATP was reproducible during multiple successive applications (Fig. $2 A$ ). This was an important prerequisite particularly when trying to assess the effect of an agonist or an antagonist (see below) on the ATPinduced change in synaptic current frequency. Furthermore, we confirmed that the miniature synaptic events that were stimulated presynaptically by ATP were GABAergic mIPSCs because they were reversibly blocked by the $\mathrm{GABA}_{\mathrm{A}}$ receptor antagonist bicuculline (Fig. 2B). When ATP triggered important increases in synaptic current frequency, we often recorded a slowly developing inward current (Fig. 2) that was attributable to the temporal summation of GABAergic mIPSCs as demonstrated by the fact that both mIPSCs and the slow current were reversibly blocked by bicuculline (Fig. 2B). In addition to its bicuculline sensitivity, this current was also characterized by a very slow rise time ( $\gg 1 \mathrm{sec})$, which was clearly distinct from that of the fast currents induced by ATP acting at postsynaptic ionotropic receptors (e.g., compare with Fig. 1D).

\section{Pharmacological properties of postsynaptic and presynaptic effects of ATP Effects of agonists}

As illustrated in Figure $3 A$, the postsynaptic current induced by ATP was reproduced by the nonhydrolyzable ATP analog ATP$\gamma$-S in all cells tested $(n=11)$. When tested at the same concentration $(100 \mu \mathrm{M})$, the amplitude of the ATP- $\gamma$-S current amounted on average $70 \pm 18 \%(n=11)$ of that induced by ATP. In contrast, $\alpha, \beta$-me-ATP $(100 \mu \mathrm{M})$, an agonist at certain homomeric and heteromeric P2X receptors (Collo et al., 1996; North and Barnard, 1997; Le et al., 1998a; Ralevic and Burnstock, 1998; Khakh et al., 1999b), did not ever induce any response in neurons in which ATP or ATP- $\gamma$-S triggered an inward current $(n=9)$. At a concentration of $10 \mu \mathrm{M}(n=11)$, ADP had no effect on cells in which ATP $(10 \mu \mathrm{M})$ induced an inward current. At $100 \mu \mathrm{M}$, ADP triggered no current in three of four cells tested and induced a current that represented $67 \%$ of that elicited by ATP $(100 \mu \mathrm{M})$ in the remaining cell. Neither ADP- $\beta$-S $(50 \mu \mathrm{M} ; n=5)$, a P2Y1 receptor agonist (Ralevic and Burnstock, 1998), nor UTP (100 $\mu \mathrm{M} ; n=6)$ triggered any response in cells responding to ATP with an inward current.

Similar observations were made for the presynaptic effect of ATP (Fig. 3B). The response to ATP $(100 \mu \mathrm{M})$ was always mimicked by ATP- $\gamma-\mathrm{S}(100 \mu \mathrm{M})$, which induced a $118 \pm 55 \%(n=$ $6)$ increase (i.e., a doubling) in mIPSC frequency. The effect of ATP- $\gamma$-S amounted to $89 \pm 38 \%$ of that of ATP $(n=5)$. In cells in which ATP or ATP- $\gamma$-S increased mIPSCs frequency, $\alpha, \beta$-meATP $(100 \mu \mathrm{M} ; n=4)$, ADP- $\beta$-S $(50 \mu \mathrm{M} ; n=6)$, and UTP (100 $\mu \mathrm{M} ; n=4)$ failed to induce any change in mIPSC frequency. In 5 of 13 neurons $(38.5 \%)$, ATP $(10 \mu \mathrm{M})$ induced an increase in mIPSC frequency, and ADP $(10 \mu \mathrm{M})$ had no effect in the same cells. In five other cells $(38.5 \%)$, ADP $(10 \mu \mathrm{M})$ had a stimulatory effect on mIPSC frequency that represented on average $55 \pm 28 \%$ of the effect of ATP $(10 \mu \mathrm{M})$. Finally, in three cells (23\%), ADP $(10 \mu \mathrm{M})$ elicited a greater effect than ATP $(10 \mu \mathrm{M})$. The ADP response represented $199 \pm 48 \%(n=3)$ of the ATP response. We never observed any effect of ADP in cells that did not respond to ATP $(n=14)$. ADP- $\beta$-S $(50 \mu \mathrm{M})$ did not reproduce the effect of ADP $(10 \mu \mathrm{M})$ in three of three cells tested.

\section{Effects of antagonists}

We compared the effects of the three classic $\mathrm{P} 2 \mathrm{X}$ receptor antagonists, suramin, reactive blue, and PPADS (Ralevic and Burnstock, 1998) on the postsynaptic and presynaptic effects of ATP. Because of the slow onset kinetics of $\mathrm{P} 2$ receptor blockade by suramin and PPADS, these two antagonists were allowed to 
A
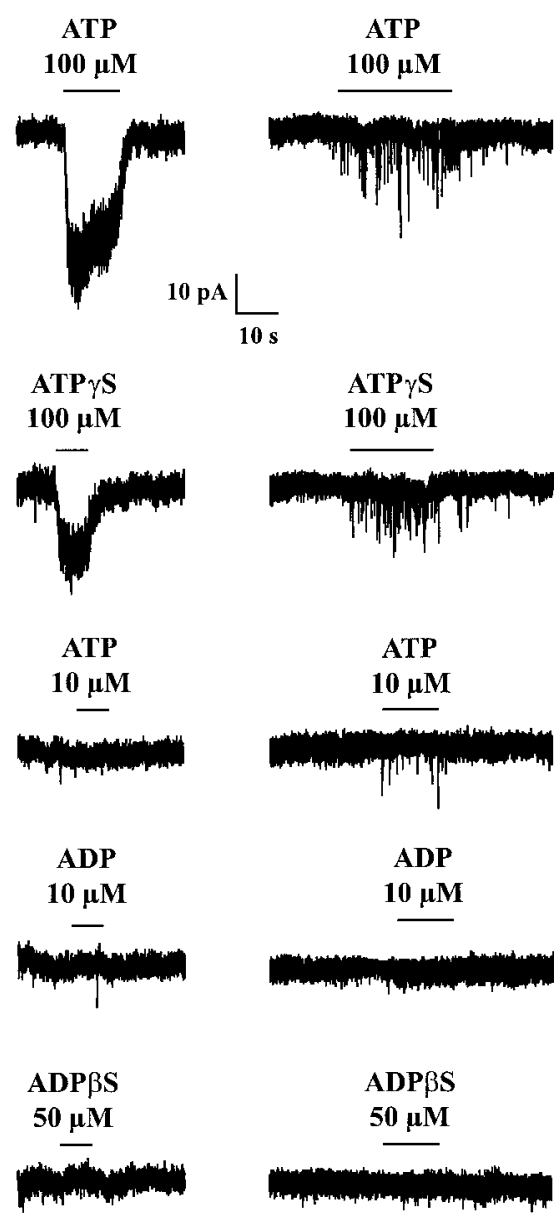

Figure 3. Effects of $\mathrm{P} 2 \mathrm{X}$ and $\mathrm{P} 2 \mathrm{Y}$ receptor agonists on cultured $\mathrm{DH}$ neurons displaying a postsynaptic $(A)$ or presynaptic $(B)$ response. $A$, ATP $(100 \mu \mathrm{M})$ induced an inward current that was partially reproduced by the same concentration of ATP- $\gamma$-S, a nonhydrolyzable analog of ATP. ATP $(10 \mu \mathrm{M})$, ADP $(10 \mu \mathrm{M})$, or ADP- $\beta$-S $(50 \mu \mathrm{M})$, an agonist at P2Y1 receptors, had no effect in the same cell. $B$, ATP $(100 \mu \mathrm{M})$ increased the frequency of GABAergic mIPSCs. This effect was mimicked by ATP- $\gamma-\mathrm{S}$ $(100 \mu \mathrm{M})$ and to a lesser extent by a lower concentration of ATP $(10 \mu \mathrm{M})$ or ADP $(10 \mu \mathrm{M})$. ADP- $\beta$-S $(50 \mu \mathrm{M})$ was without effect. For each panel (column), all recordings were from the same cell. HP, $-60 \mathrm{mV}$.

equilibrate in the extracellular medium before being coapplied with ATP. In contrast, reactive blue blocks P2X receptors rapidly, and we tested its effect during coapplication with ATP in the absence of reactive blue in bath (Le et al., 1998a). The results obtained are summarized in Figure 4.

At the postsynaptic level, the current induced by ATP $(100 \mu \mathrm{M})$ was inhibited in an apparently dose-dependent manner by suramin and reactive blue. The percentages of inhibition were of $18 \pm 19 \%(n=5$, range $0-50 \%)$ and $64 \pm 28 \%(n=5$, range $20-100 \%$ ) for 1 and $30 \mu \mathrm{M}$ suramin, respectively, and of $32 \pm$ $27 \%(n=6,0-70 \%)$ and $84 \pm 20 \%(n=4$, range $50-100 \%)$ for 1 and $10 \mu \mathrm{M}$ reactive blue. PPADS was tested at a single concentration of $50 \mu \mathrm{M}$ and inhibited the ATP response by $87 \pm 19 \%$ ( $n=3$, range $60-100 \%)$.

At the presynaptic level, the use of these antagonists was more delicate because they tended to block directly GABAergic mIP$\mathrm{SCs}$ by a mechanism independent of $\mathrm{P} 2$ receptors that was attributable to a direct inhibition of $\mathrm{GABA}_{\mathrm{A}}$ receptors (Ralevic and
$\mathbf{A}$

POSTSYNAPTIC EFFECT

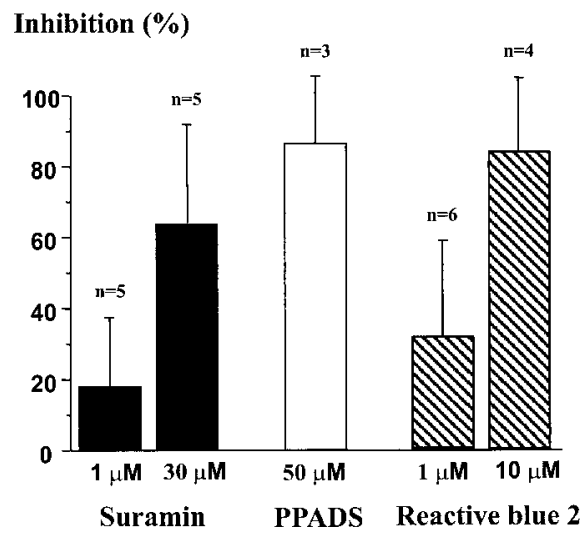

B

PRESYNAPTIC EFFECT

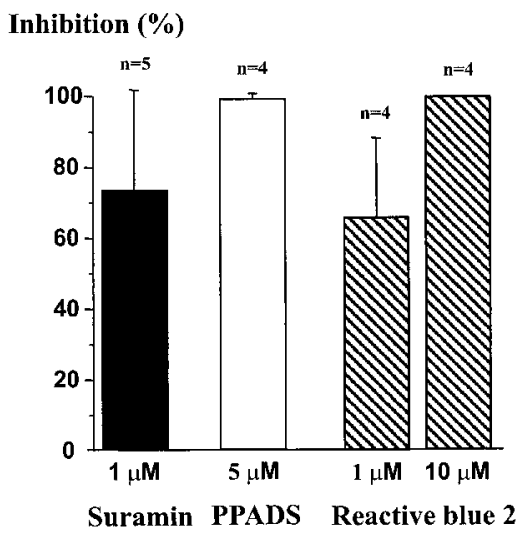

Figure 4. Effects of P2X receptor antagonists on postsynaptic and presynaptic actions of ATP. Different concentrations of suramin (black bars), PPADS (white bar), and reactive blue 2 (hatched bars) were tested on postsynaptic $(A)$ and presynaptic $(B)$ responses to ATP $(100 \mu \mathrm{M})$. The histogram represents the percentage of inhibition by each antagonist of the control response to ATP, which was determined as the amplitude of the membrane current (POSTSYNAPTIC EFFECT) or the increase in frequency of mIPSCs (PRESYNAPTIC EFFECT) induced by ATP $(100 \mu \mathrm{M})$ in the absence of antagonists. Error bars represent SEM. HP, $-60 \mathrm{mV}$.

Burnstock, 1998; Jo and Schlichter, 1999). Therefore, we decided to test the effect of lower concentrations of these antagonists on the presynaptic response to ATP to avoid nonspecific effects as much as possible. We first verified the effect of such low concentrations of $\mathrm{P} 2$ receptor antagonists on the postsynaptic whole-cell $\mathrm{Cl}^{-}$current induced by local application of a nonsaturating concentration $(20 \mu \mathrm{M})$ of the selective $\mathrm{GABA}_{\mathrm{A}}$ receptor agonist isoguvacine. Suramin $(1 \mu \mathrm{M})$ and PPADS $(5 \mu \mathrm{M})$ had no effect on the amplitude of the isoguvacine current $(n=5)$, and reactive blue $(10 \mu \mathrm{M})$ inhibited the $\mathrm{GABA}_{\mathrm{A}}$ receptor-gated current by $21 \pm 10 \%(n=7$, range $0-33 \%)$. As illustrated in Figure $4 B$, at concentrations as low as 1 or $5 \mu \mathrm{M}$, these antagonists potently inhibited the presynaptic effect of ATP but had no detectable effect on mIPSC characteristics or frequency on their own. The mean percentages of inhibition of the ATP effect were $85 \pm 13 \%$ $(n=5$, range $65-100 \%), 66 \pm 22 \%(n=5$, range $40-100 \%)$, and $100 \%(n=4)$ for suramin $(1 \mu \mathrm{M})$, reactive blue $(1 \mu \mathrm{M})$, and PPADS $(5 \mu \mathrm{M})$, respectively. Perfusion of suramin $(1 \mu \mathrm{M}, n=5)$ 




C



D



$\mathbf{E}$

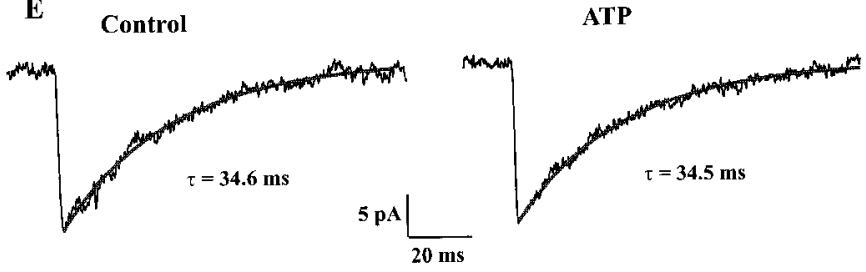

Figure 5. ATP increased the frequency but did not alter the amplitude or the kinetic characteristics of GABAergic mIPSCs. $A, B$, In a neuron displaying mIPSCs under control conditions $(A)$, application of ATP $(100$ $\mu \mathrm{M})$ markedly increased the frequency of these synaptic currents $(B) . C$, Cumulative probability histogram of time intervals between successive mIPSCs, before and during ATP $(100 \mu \mathrm{M})$ application. ATP shifted the distribution of interevent intervals to the left, indicating an increase in mIPSC frequency. $D$, Cumulative probability histogram of mIPSC amplitudes. Both distributions match perfectly and were not significantly different (Kolmogorov-Smirnov test), indicating that ATP did not modify the amplitude of mIPSCs. E, ATP $(100 \mu \mathrm{M})$ had no effect on mIPSCs decay kinetics. Averaged traces from 10 events recorded under control conditions (left trace) or during application of $100 \mu \mathrm{M} \mathrm{ATP} \mathrm{(right} \mathrm{trace)} \mathrm{are}$ represented. $\tau$ is the value of the time constant of the single exponential fit represented as the solid line superimposed on each trace. All data are from the same neuron. HP, $-60 \mathrm{mV}$.

or PPADS ( $5 \mu \mathrm{M}, n=4)$ alone did not significantly modify the basal frequency of mIPSCs ( $t$ test, $p>0.05$ ), suggesting the absence of a tonic $\mathrm{P} 2 \mathrm{X}$ receptor-mediated facilitatory component on GABA release under the prevailing experimental conditions.

Taken together, our results indicate that the postsynaptic and presynaptic ATP receptors detected in our study had a similar pharmacological profile that was consistent with the involvement of $\mathrm{P} 2 \mathrm{X}$ receptors in the observed effects.

\section{ATP does not alter mIPSC kinetics}

The major effect of ATP or ATP- $\gamma$-S on GABAergic synaptic transmission was to increase mIPSC frequency, indicating a presynaptic site of action (Fig. $5 A-C$ ). As mentioned above, the mean increase in frequency was $257 \pm 197 \%(n=33)$. To determine whether a postsynaptic modulation of mIPSCs was also involved, we analyzed in more detail the amplitude distribution and the kinetic characteristics (rise time, deactivation time constant) of GABAergic mIPSCs before and during application of ATP (100 $\mu \mathrm{M})$. In this analysis we considered only cells in which ATP induced an increase in mIPSC frequency without inducing an inward current at the postsynaptic level, because the development of such a current was always associated with an increase in membrane noise that could interfere with the detection of mIPSC and the analysis of their kinetic characteristics. As shown in Figure $5 D$, the amplitude distribution of mIPSCs was similar under control conditions or in the presence of ATP (Kolmogorov-Smirnov test). This was true in all cases examined $(n=9)$. Similarly, the RTs and monoexponential deactivation time constants $(\tau)$ of mIPSCs were unaffected by ATP (Fig. $5 E$ ). The values for RTs were $1.88 \pm 0.43 \mathrm{msec}$ and $1.85 \pm 0.40 \mathrm{msec}(n=$ $8)$ in the absence and presence of ATP $(100 \mu \mathrm{M})$, respectively $(t$ test, $p>0.05)$. Similarly, the values of $\tau$ were of $33.1 \pm 3.9 \mathrm{msec}$ and $35.3 \pm 4.0 \mathrm{msec}(n=8)$ in the absence and presence of ATP $(100 \mu \mathrm{M})$ respectively $(t$ test, $p>0.05)$.

\section{Calcium dependence of the presynaptic effect of ATP}

We next determined the contribution of intracellular versus extracellular $\mathrm{Ca}^{2+}$ to the presynaptic stimulatory effect of ATP on mIPSC frequency.

\section{Intracellular $\mathrm{Ca}^{2+}$ stores}

To assess the role of intracellular $\mathrm{Ca}^{2+}$ stores, we tested the effect of thapsigargin, which blocks the $\mathrm{Ca}^{2+}$ pump of the endoplasmic reticulum and therefore prevents the refilling of intracellular $\mathrm{Ca}^{2+}$ stores. In particular, thapsigargin was shown to block the ATP-induced elevation of free intracellular $\mathrm{Ca}^{2+}$ concentration mediated by the activation of $\mathrm{P} 2 \mathrm{Y}$ receptors in dorsal horn astrocytes (Salter and Hicks, 1994, 1995). We first elicited control responses to ATP $(100 \mu \mathrm{M})$ before superfusing the cells with thapsigargin $(1 \mu \mathrm{M})$. Bath application of thapsigargin $(1 \mu \mathrm{M})$ elicited a transient stimulation of mIPSC frequency that returned to control levels $5 \mathrm{~min}$ after onset of superfusion. This phenomenon probably reflected the thapsigargin-induced release of $\mathrm{Ca}^{2+}$ from reticular stores. We then applied ATP $(100 \mu \mathrm{M})$ in the steady presence of thapsigargin $(1 \mu \mathrm{M})$ at 2 min intervals for periods up to $30 \mathrm{~min}$ (15 applications). A typical result is illustrated in Figure $6 A$. In the presence of thapsigargin, ATP still elicited an increase in mIPSC frequency in all cells tested $(n=4)$. To try to quantify the effect of thapsigargin on the ATP effect, we compared the control ATP response to the third or fourth response to ATP in the presence of thapsigargin. Under these conditions, the response to ATP in the presence of thapsigargin represented $62 \pm 29 \%(n=4$, range $26-94 \%)$ of the control response to ATP. By comparing the increase in MIPSC frequency triggered by ATP in the absence and in the presence of thapsigargin ( $t$ test), we found that the apparent inhibition of the ATP response observed in the presence of thapsigargin was not significant at a 0.05 confidence interval.

\section{Role of extracellular $\mathrm{Ca}^{2+}$}

The stimulatory effect of ATP $(100 \mu \mathrm{M})$ on mIPSC frequency was completely and reversibly blocked when the external $\mathrm{Ca}^{2+}$ concentration was lowered to $0.3 \mathrm{~mm}$. This was observed in all cells tested $(n=5)$ and indicated a complete dependence of the presynaptic effect on $\mathrm{Ca}^{2+}$ influx. We then tried to assess the eventual contribution of a direct $\mathrm{Ca}^{2+}$ influx through presynaptic $\mathrm{P} 2 \mathrm{X}$ receptors. We used an experimental protocol similar to the one that we had developed to characterize the $\mathrm{Ca}^{2+}$ permeability 
A

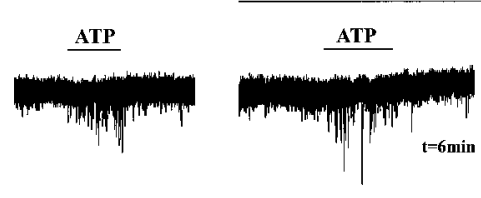

B



Thapsigargin

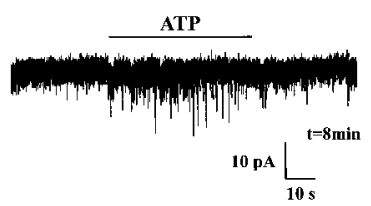

Table 1. Effect of ATP (100 $\mu \mathrm{M})$ on electrically evoked GABAergic IPSCs from neurons coreleasing ATP and GABA or releasing only GABA

\begin{tabular}{lll} 
& $\begin{array}{l}\text { Neurons coreleasing } \\
\text { ATP and GABA }\end{array}$ & $\begin{array}{l}\text { Neurons releasing } \\
\text { only GABA }\end{array}$ \\
\hline Facilitatory effect of ATP & 5 & 2 \\
No effect of ATP & 1 & 3
\end{tabular}

Among the 11 neurons tested, 6 coreleased ATP and GABA (first column) and 5 released only GABA (second column). Electrically evoked GABAergic IPSCs were recorded at an $\mathrm{HP}$ of $0 \mathrm{mV}$.



Figure 7. Effect of ATP on GABAergic eIPSCs. A paired-pulse stimulation protocol consisting of two identical electrical pulses $(0.1 \mathrm{msec}$ duration) separated by $400 \mathrm{msec}$ was applied at a frequency of $0.1 \mathrm{~Hz}$. Arrows indicate the stimulation artifacts corresponding to the electrical stimuli. In the presence of ATP $(100 \mu \mathrm{M}$, bold trace $)$, the amplitude of both eIPSCs was increased (potentiation of the first eIPSC, 18\%; potentiation of the second eIPSC, 29\%), and the paired-pulse ratio was decreased (by 50\%), indicating a presynaptic mechanism of action. The effect of ATP was completely reversible (data not shown). The control and wash traces are averages of 20 individual consecutive traces and that in ATP is an average of 10 traces. $\mathrm{HP}, 0 \mathrm{mV}$. NMDG-containing extracellular solution to prevent $\mathrm{Na}^{+}$ dependent membrane depolarization associated with the activation of presynaptic $\mathrm{P} 2 \mathrm{X}$ receptors, which are nonselective cation channels. For applications lasting $<20 \mathrm{sec}, \mathrm{P} 2 \mathrm{X}$ receptors are essentially impermeable to NMDG (Khakh et al., 1999a; Virginio et al., 1999) and ATP-induced $\mathrm{Ca}^{2+}$ influx can only occur through activated $\mathrm{P} 2 \mathrm{X}$ receptors and not through voltagedependent $\mathrm{Ca}^{2+}$ channels (Poisbeau et al., 1994). Under such experimental conditions, ATP $(100 \mu \mathrm{M})$ still caused an increase in mIPSC frequency (Fig. $6 B)$ in all cells tested $(n=4)$. This response represented $25 \pm 10 \%$ of the ATP response recorded under control conditions. When the extracellular $\mathrm{Ca}^{2+}$ concentration was reduced to $0.3 \mathrm{~mm}$ in the absence of external $\mathrm{Na}^{+}$, the stimulatory effect of ATP on mIPSC frequency was no longer observed $(n=4)$ (Fig. $6 B$ ). Returning to a medium containing 2.5 mM $\mathrm{Ca}^{2+}$ resulted in a the recovery of the ATP effect. Similar observations were made in all cells tested $(n=3)$.

Taken together, these results indicated that the presynaptic effect of ATP depended essentially on $\mathrm{Ca}^{2+}$ influx, a substantial fraction of which $(\sim 25 \%)$ was probably the result of influx through presynaptic $\mathrm{P} 2 \mathrm{X}$ receptors.

\section{Effect of ATP on GABAergic elPSCs}

Electrical stimulation of a presynaptic neuron that was visually identified as establishing an apparent physical contact with the neuron from which we recorded was performed as described previously (Jo et al., 1998a; Jo and Schlichter, 1999). These experiments were performed in the absence of TTX but in the presence of strychnine, CNQX, and APV. The equilibrium for

$\mathrm{Cl}^{-}$ions was set at $-90 \mathrm{mV}$ and that for cations at $0 \mathrm{mV}$ to detect the synaptic corelease of ATP and GABA (see Materials and Methods). Under these conditions the eIPSCs could be recorded in isolation at an $\mathrm{HP}$ of $0 \mathrm{mV}$, and the $\mathrm{P} 2 \mathrm{X}$ receptor-mediated EPSCs could be recorded at an HP of $-90 \mathrm{mV}$.

The effect of ATP $(100 \mu \mathrm{M})$ was tested in a total of 11 cells. In six cases, ATP and GABA were coreleased synaptically from the presynaptic neuron, whereas in the five other cases GABA was released alone. Table 1 summarizes the results that we obtained. ATP potentiated GABAergic eIPSCs in $64 \%$ (7 of 11) of the neurons tested. This potentiating effect was detected in neurons that released only GABA (two of seven, 29\%) but was preferentially observed in neurons coreleasing GABA and ATP (five of seven neurons, 71\%). Interestingly, the neurons in which ATP had no effect on eIPSCs belonged mainly to the category of neurons that released only GABA (three of four, $75 \%$ ).

Figure 7 illustrates a typical effect of ATP $(100 \mu \mathrm{M})$ on GABAergic eIPSCs evoked by paired-pulse stimulation of the presynaptic neuron (see Materials and Methods). ATP increased on average the amplitude of the first eIPSC by $25 \pm 9 \%(n=7)$ and reduced the paired-pulse inhibition or facilitation ratio by $54 \pm 26 \%(n=7)$. These effects were reversible and indicated that ATP facilitated GABAergic transmission by acting presynaptically. The monoexponential decay time constants of the first and second eIPSCs were $89 \pm 16 \mathrm{msec}$ and $101 \pm 30 \mathrm{msec}$ under 
control conditions and $92 \pm 14 \mathrm{msec}$ and $101 \pm 26 \mathrm{msec}$ in the presence of ATP $(n=7)$. There was no significant difference between the decay time constants of the first and second eIPSCs under either condition (control or in the presence of ATP) ( $t$ test, $p>0.05)$. ATP did not modify the monoexponential decay time constants of the first and second eIPSCs with respect to control $(t$ test, $p>0.05)$.

\section{DISCUSSION}

Our study demonstrates the presence of functional receptors for ATP (P2 receptors) on a subpopulation of cultured laminae I-III DH neurons. The novel finding was that ATP facilitated GABAergic synaptic transmission by a presynaptic mechanism involving $\mathrm{Ca}^{2+}$-permeable ionotropic $\mathrm{P} 2 \mathrm{X}$ receptors, the pharmacological profile of which appeared to be dominated by the P2X2 subunit.

\section{Existence of functional postsynaptic and presynaptic ATP receptors}

ATP $(10-100 \mu \mathrm{M})$ induced an inward current in a subset $(38 \%)$ of cultured laminae I-III DH neurons. This proportion of neurons was comparable to that displaying $\mathrm{P} 2 \mathrm{X}$ receptor-mediated excitatory postsynaptic currents in the same preparation (Jo and Schlichter, 1999), and our results are in line with those of earlier studies demonstrating the presence of functional ATP receptors on DH neurons (Jahr and Jessell, 1983; Salter et al., 1993; Li and Perl, 1995).

A novel finding was that ATP increased the frequency of $\mathrm{GABA}_{\mathrm{A}}$ receptor-mediated mIPSCs and the amplitude of eIPSCs. ATP did not modify the amplitude of mIPSCs or the kinetic properties of mIPSCs or eIPSCs, indicating a purely presynaptic effect on receptors located close to the presynaptic terminal. This effect was similar to the previously described P2X receptor-mediated facilitation of glutamate release from terminals of primary afferent neurons in the DH (Li and Perl, 1995; Gu and MacDermott, 1997; Li et al., 1998) and in the brain stem (Khakh and Henderson, 1998) or of noradrenaline release from sympathetic neurons (Boehm, 1999), but it constitutes the first demonstration of a modulatory effect of ATP on inhibitory synaptic transmission between neurons of the CNS. Moreover, the effect of ATP was observed in a subset $(\sim 22 \%)$ of GABAergic neurons and in a small proportion $(9 \%)$ of glycinergic neurons but was never detected in the case of glutamatergic neurons, suggesting a specific effect of ATP on inhibitory versus excitatory transmission between DH neurons.

The presynaptic effect of ATP was completely dependent on $\mathrm{Ca}^{2+}$ influx and was not significantly affected by thapsigargin, indicating a minor contribution of intracellular $\mathrm{Ca}^{2+}$ stores. This situation is therefore clearly distinct from that in cultured $\mathrm{DH}$ astrocytes in which the cellular response to ATP is entirely dependent on the release of $\mathrm{Ca}^{2+}$ from thapsigargin-sensitive intracellular stores after activation of metabotropic P2Y/P2U receptors (Salter and Hicks, 1994, 1995; Ho et al., 1995).

\section{Pharmacological properties of ATP effects}

Both presynaptic and postsynaptic effects of ATP were sensitive to low concentrations of suramin and PPADS, indicating the involvement of ionotropic P2X-type receptors (Ralevic and Burnstock, 1998). Neither UTP, an agonist at many P2Y (except P2Y1) receptors, nor ADP- $\beta$-S, an agonist at P2Y1 receptors (North and Barnard, 1997; Ralevic and Burnstock, 1998), reproduced the effects of ATP, indicating that metabotropic P2Y purinoceptors were probably not involved. ADP mimicked the presynaptic effect of ATP in a subset of neurons but was usually less potent than ATP when tested at the same concentration, consistent with the activation of $\mathrm{P} 2 \mathrm{X}$ receptors by ADP (Ralevic and Burnstock, 1998).

\section{Subunit composition of $\mathrm{P} 2 \mathrm{X}$ receptors in DH neurons}

In situ hybridization and immunocytochemical experiments have demonstrated that $\mathrm{P} 2 \mathrm{X} 2, \mathrm{P} 2 \mathrm{X} 4$, and $\mathrm{P} 2 \mathrm{X} 6$ subunits are expressed in laminae I-II of the DH (Collo et al., 1996; Vulchanova et al., 1997; Le et al., 1998b; Kanjhan et al., 1999). Interestingly, P2X2 is expressed only in lamina II, and lamina III expresses none of the known (P2X1-7) subunits (Collo et al., 1996). P2X4 (Le et al., 1998b) and P2X2 (Kanjhan et al., 1999) have also been localized to presynaptic terminals and could therefore underlie the facilitation of synaptic GABA release observed in our study.

Most P2X subunits can form functional homomeric or heteromeric receptors or both, but interestingly only a limited number of combinations are likely to occur in our system. P2X2 and P2X4 but not P2X6 subunits can form functional homomeric receptors (Collo et al., 1996; Le et al., 1998a; Khakh et al., 1999b; Torres et al., 1999). However, P2X6 can heteromerize with both P2X2 and P2X4, whereas P2X2 and P2X4 do not assemble (Collo et al., 1996; Le et al., 1998a; Khakh et al., 1999b; Torres et al., 1999). These considerations suggest that the combinations that might occur in the superficial DH include homomeric $\mathrm{P} 2 \mathrm{X} 2$ or $\mathrm{P} 2 \mathrm{X} 4$ receptors or both as well as heteromeric P2X2/P2X6, P2X4/P2X6 and speculatively $\mathrm{P} 2 \mathrm{X} 2 / \mathrm{P} 2 \mathrm{X} 4 / \mathrm{P} 2 \mathrm{X} 6$ receptors.

Homomeric $\mathrm{P} 2 \mathrm{X} 2$ receptors are sensitive to low concentrations of the antagonists suramin and PPADS and are insensitive to the agonist $\alpha \beta$-me-ATP. By contrast, P2X 4 homomers are insensitive to suramin and PPADS at concentrations $<100 \mu \mathrm{M}$ and show low sensitivity to $\alpha \beta$-me-ATP (Collo et al., 1996; North and Barnard, 1997; Le et al., 1998a; Ralevic and Burnstock, 1998; Khakh et al., 1999b). Interestingly, heteromeric P2X4/P2X6 receptors give rise to a novel phenotype that is sensitive to suramin, PPADS, and $\alpha \beta$-me-ATP and is potentiated by reactive blue (Le et al., 1998a), which otherwise is an antagonist at $\mathrm{P} 2 \mathrm{X}$ receptors (Ralevic and Burnstock, 1998). In our preparation, the postsynaptic and presynaptic effects of ATP were antagonized by suramin, PPADS, and reactive blue, and $\alpha \beta$-me-ATP $(100 \mu \mathrm{M})$ was never able to reproduce the effects of ATP. This pharmacological profile was similar to that of homomeric $\mathrm{P} 2 \mathrm{X} 2$ receptors and indicated that neither homomeric $\mathrm{P} 2 \mathrm{X} 4$ nor heteromeric $\mathrm{P} 2 \mathrm{X} 4 / \mathrm{P} 2 \mathrm{X} 6$ receptors were involved. However, the presence of $\mathrm{P} 2 \mathrm{X} 4$ receptors on presynaptic boutons and on cell bodies and dendrites in laminae I-II was clearly demonstrated in situ (Le et al., 1998b). Although we cannot completely rule out the possibility that the expression profile of $\mathrm{P} 2 \mathrm{X}$ subunits is slightly different from that in situ, two major possibilities can be envisaged: (1) ATP receptors are P2X2 homomers, and the P2X4 subunits localized by electron microscopy were not assembled into functionally detectable receptors (Garcia-Lecea et al., 1999; Khakh et al., 1999b), or (2) the receptors comprised both $\mathrm{P} 2 \mathrm{X} 2$ and $\mathrm{P} 2 \mathrm{X} 4$ subunits, their pharmacological profile being governed by P2X2. P2X2 and P2X4 subunits do not coassemble, but P2X6 subunits can heteromerize with either P2X2 or P2X4 (Torres et al., 1999). It is therefore tempting to speculate that the functional $\mathrm{P} 2 \mathrm{X}$ receptors of $\mathrm{DH}$ neurons, in particular those controlling GABA release, are heteromers composed of three distinct subunits (P2X2, P2X4, and $\mathrm{P} 2 \mathrm{X} 6$ ), $\mathrm{P} 2 \mathrm{X} 6$ playing the role of a linker subunit between $\mathrm{P} 2 \mathrm{X} 2$ and $\mathrm{P} 2 \mathrm{X} 4$ and possibly contributing to limiting the formation of P2X4 homomers that otherwise form easily and preferentially 
(Le et al., 1998a; Torres et al., 1999). However, a direct confirmation of this hypothesis will have to await pharmacological tools that allow a clear discrimination between different native P2X subunit combinations and co-precipitation experiments designed to determine the assembly of three different types of subunits.

\section{Origin of ATP and physiological significance}

ATP is present at high concentration in synaptic vesicles containing classical neurotransmitters and is therefore likely to be released synaptically with these transmitters. However, the detection of ATP release relies on the presence of functional postsynaptic $\mathrm{P} 2 \mathrm{X}$ or $\mathrm{P} 2 \mathrm{Y}$ receptors and on the fact that a sufficient amount of ATP is released to reach the postsynaptic membrane without being degraded by extracellular or secreted ectonucleotidases (Zimmermann, 1994; Todorov et al., 1997). Thus, corelease of ATP with classical transmitters could be a common phenomenon but might be detected only in a small number of cases (Jo and Schlichter, 1999). Our electrical stimulation experiments showed that presynaptic P2X receptors are preferentially, but not exclusively, localized on terminals of DH neurons that corelease ATP and GABA, suggesting that they might act as facilitatory autoreceptors (Boehm, 1999). We have preliminary evidence that the amplitude of GABAergic eIPSCs is inhibited by $\sim 10 \%$ during the application of PPADS $(5 \mu \mathrm{M})$ to neurons coreleasing ATP and GABA (our unpublished observation). Although this effect is similar to that reported for sympathetic neurons (Boehm, 1999), this finding must be interpreted with caution, and the clear demonstration of functional P2X autoreceptors will have to await the development of selective antagonists that do not interact with $\mathrm{GABA}_{\mathrm{A}}$ receptors.

It is known that ATP is released from primary afferent terminals in the DH (for review, see Salter et al., 1993), from intrinsic DH neurons (Sawynok et al., 1993; Jo and Schlichter, 1999) (which might be different from those coreleasing ATP and GABA), and from astrocytes (Queiroz et al., 1997), and ATP appears to be the extracellular messenger that allows the propagation of $\mathrm{Ca}^{2+}$ waves between astrocytes (Guthrie et al., 1999). In a physiological context, one could speculate that the initial release of ATP from neurons could elicit $\mathrm{Ca}^{2+}$ waves in perisynaptic glial cells, as has already been demonstrated at the neuromuscular junction (Robitaille, 1995), which could then propagate locally via the astrocyte network and regulate presynaptically or postsynaptically the transmission at nearby synapses via either ATP receptors or receptors to another neuroactive substance released by glial cells. Although this type of modulation has to be clearly established, it certainly would represent an interesting form of local and activity-dependent modulation of neurotransmission involving neuroglial interactions.

\section{REFERENCES}

Bardoni R, Goldstein PA, Lee CJ, Gu JG, MacDermott AB (1997) ATP $\mathrm{P} 2 \mathrm{X}$ receptors mediate fast synaptic transmission in the dorsal horn of the rat spinal cord. J Neurosci 17:5297-5304.

Boehm S (1999) ATP stimulates sympathetic transmitter release via presynaptic P2X purinoceptors. J Neurosci 19:737-746.

Burnashev N (1996) Calcium permeability of glutamate-gated channels in the central nervous system. Curr Opin Neurobiol 6:311-317.

Burnstock G (1997) The past, present and future of purine nucleotides as signalling molecules. Neuropharmacology 36:1127-1139.

Collo G, North RA, Kawashima E, Merlo-Pich E, Neidhart S, Surprenant A, Buell G (1996) Cloning of P2X5 and P2X6 receptors and the distribution and properties of an extended family of ATP-gated ion channels. J Neurosci 16:2495-2507.

Edwards FA, Gibb AJ, Colquhoun D (1992) ATP receptor-mediated synaptic currents in the central nervous system. Nature 359:144-147.

Garcia-Lecea M, Delicado EG, Miras-Portugal MT, Castro E (1999) P2X2 characteristics of the ATP receptor coupled to $\left[\mathrm{Ca}^{2+}\right]_{\mathrm{i}}$ increases in cultured Purkinje neurons from neonatal rat cerebellum. Neuropharmacology 38:699-706.

Gu JG, MacDermott AB (1997) Activation of ATP P2X receptors elicits glutamate release from sensory neuron synapses. Nature 389:749-753.

Guthrie PB, Knappenberger J, Segal M, Bennett MVL, Charles AC, Kater SB (1999) ATP released from astrocytes mediates glial calcium waves. J Neurosci 19:520-528.

Ho C, Hicks J, Salter MW (1995) A novel P2-purinoceptor expressed by a subpopulation of astrocytes from the dorsal spinal cord of the rat. $\mathrm{Br} \mathrm{J}$ Pharmacol 116:2909-2918.

Jahr CE, Jessell TM (1983) ATP excites a subpopulation of rat dorsal horn neurones. Nature 304:730-733.

Jo YH, Schlichter R (1999) Synaptic corelease of ATP and GABA in cultured spinal neurons. Nat Neurosci 2:241-245.

Jo YH, Stoeckel ME, Freund-Mercier MJ, Schlichter R (1998a) Oxytocin modulates glutamatergic synaptic transmission between cultured neonatal spinal cord dorsal horn neurons. J Neurosci 18:2377-2386.

Jo YH, Stoeckel ME, Schlichter R (1998b) Electrophysiological properties of cultured neonatal rat dorsal horn neurons containing GABA and met-enkephalin-like immunoreactivity. J Neurophysiol 79:1583-1586.

Jonas P, Burnashev N (1995) Molecular mechanisms controlling calcium entry through AMPA-type glutamate receptor channels. Neuron 15:987-990.

Kanjhan R, Housley GD, Burton LD, Christie DL, Kippenberger A, Thorne PR, Luo L, Ryan AF (1999) Distribution of the P2X2 receptor subunit of the ATP-gated ion channels in the rat central nervous system. J Comp Neurol 407:11-32.

Khakh BS, Henderson G (1998) ATP receptor-mediated enhancement of fast excitatory neurotransmitter release in the brain. Mol Pharmacol 54:372-378.

Khakh BS, Bao XR, Labarca C, Lester HA (1999a) Neuronal P2X transmitter-gated cation channels change their ion selectivity in seconds. Nat Neurosci 2:322-330.

Khakh BS, Proctor WR, Dunwiddie TV, Labarca C, Lester HA (1999b) Allosteric control of gating and kinetics at $\mathrm{P} 2 \mathrm{X}(4)$ receptor channels. J Neurosci 19:7289-7299.

Le KT, Babinski K, Seguela P (1998a) Central P2X4 and P2X6 channel subunits coassemble into a novel heteromeric ATP receptor. J Neurosci 18:7152-7159.

Le KT, Villeneuve P, Ramjaun AR, McPherson PS, Beaudet A, Seguela P (1998b) Sensory presynaptic and widespread somatodendritic immunolocalization of central ionotropic P2X ATP receptors. Neuroscience 83:177-190.

Li J, Perl ER (1995) ATP modulation of synaptic transmission in the spinal substantia gelatinosa. J Neurosci 15:3357-3365.

Li P, Calejesan AA, Zhuo M (1998) ATP P2x receptors and sensory synaptic transmission between primary afferent fibers and spinal dorsal horn neurons in rats. J Neurophysiol 80:3356-3360.

MacDermott AB, Role LW, Siegelbaum SA (1999) Presynaptic ionotropic receptors and the control of transmitter release. Annu Rev Neurosci 22:443-485.

Millan MJ (1999) The induction of pain: an integrative review. Prog Neurobiol 57:1-164.

Nieber K, Poelchen W, Illes P (1997) Role of ATP in fast excitatory synaptic potentials in locus coeruleus neurones of the rat. Br J Pharmacol 122:423-430.

North RA, Barnard EA (1997) Nucleotide receptors. Curr Opin Neurobiol 7:346-357.

Pankratov Y, Castro E, Miras-Portugal MT, Krishtal O (1998) A purinergic component of the excitatory postsynaptic current mediated by $\mathrm{P} 2 \mathrm{X}$ receptors in the CA1 neurons of the rat hippocampus. Eur J Neurosci 10:3898-3902.

Poisbeau P, Trouslard J, Feltz P, Schlichter R (1994) Calcium influx through neuronal-type nicotinic acetylcholine receptors present on the neuroendocrine cells of the porcine pars intermedia. Neuroendocrinology 60:378-388.

Poisbeau P, René F, Egles C, Félix JM, Feltz P, Schlichter R (1996) Characterization of functional GABAergic synapses formed between hypothalamic neurons and pituitary intermediate lobe cells in cocul- 
ture: $\mathrm{Ca}^{2+}$-dependence of spontaneous IPSCs. J Neurosci 16:4835-4845.

Queiroz G, Gebicke-Haerter PJ, Schobert A, Starke K, von Kugelgen I (1997) Release of ATP from cultured rat astrocytes elicited by glutamate receptor activation. Neuroscience 78:1203-1208.

Rae J, Cooper K, Gates P, Watsky M (1991) Low access resistance perforated patch recordings using amphotericin B. J Neurosci Methods 37:15-26.

Ralevic V, Burnstock G (1998) Receptors for purines and pyrimidines. Pharmacol Rev 50:413-492.

Robitaille R (1995) Purinergic receptors and their activation by endogenous purines at perisynaptic glial cells of the frog neuromuscular junction. J Neurosci 15:7121-7131.

Salter MW, Hicks JL (1994) ATP-evoked increases in intracellular calcium in neurons and glia from the dorsal spinal cord. J Neurosci 14:1563-1575.

Salter MW, Hicks JL (1995) ATP causes release of intracellular $\mathrm{Ca}^{2+}$ via the phospholipase C beta/IP3 pathway in astrocytes from the dorsal spinal cord. J Neurosci 15:2961-2971.

Salter MW, De Koninck Y, Henry JL (1993) Physiological roles for adenosine and ATP in synaptic transmission in the spinal dorsal horn. Prog Neurobiol 41:125-156.

Sawynok J, Downie JW, Reid AR, Cahill CM, White TD (1993) ATP release from dorsal spinal cord synaptosomes: characterization and neuronal origin. Brain Res 610:32-38.

Surprenant A, Buell G, North RA (1995) P2X receptors bring new structure to ligand-gated ion channels. Trends Neurosci 18:224-229.

Todorov LD, Mihaylova-Todorova S, Westfall TD, Sneddon P, Kennedy C, Bjur RA, Westfall DP (1997) Neuronal release of soluble nucleotidases and their role in neurotransmitter inactivation. Nature 387:76-79.

Torres GE, Egan TM, Voigt MM (1999) Hetero-oligomeric assembly of $\mathrm{P} 2 \mathrm{X}$ receptor subunits. Specificities exist with regard to possible partners. J Biol Chem 274:6653-6659.

Virginio C, MacKenzie A, Rassendren FA, North RA, Surprenant A (1999) Pore dilation of neuronal P2X receptor channels. Nat Neurosci 2:315-321.

Vulchanova L, Riedl MS, Shuster SJ, Buell G, Surprenant A, North RA, Elde R (1997) Immunohistochemical study of the P2X2 and P2X3 receptor subunits in rat and monkey sensory neurons and their central terminals. Neuropharmacology 36:1229-1242.

Zimmermann H (1994) Signalling via ATP in the nervous system. Trends Neurosci 17:420-426.

Zimmermann H (1996) Biochemistry, localization and functional roles of ecto-nucleotidases in the nervous system. Prog Neurobiol 49:589618. 